\title{
EFL teachers' role in English: Letting the silent majority voice their words
}

\author{
Esmat Babaii, Mahmood Reza Atai \\ \& Abbas Parsazadeh \\ Kharazmi University \\ Tehran, Iran
}

\begin{abstract}
With the advent of the global perspective on English, the live issues of the ownership and culture of English (Akbari, 2008; Seidlhofer, 2005) have begun to shake up numerous conventional notions of the field. In the wake of this landmark shift, this study attempts to probe EFL teachers' cultural attitude toward prospective English words. To this end, identifying twelve highly Persian culture-specific words, the researchers devised an attitude questionnaire, which was administered to 351 EFL teachers to examine their right of cultural encoding (Kirkpatrick, 2014) as English users. The study concludes with granting a legitimate norm-overriding role to EFL teachers in order to gate-keep their required concepts in English.
\end{abstract}

Key words: culture-specific words; English as a lingua franca (ELF); norm-overriding role.

\section{Introduction}

The English language, unlike any other language, has reached a very distinctive state, thanks to its singular role as the most common international language, a point which in turn has brought about heated controversy. At the heart of such controversy lies the issue of the ownership of English, its cultural contents in particular (Gilmore, 2007; Xiao-Yi, 2008). To touch on this issue, it needs to be mentioned that a number of eminent scholars (Seidlhofer, 2005; Pennycook, 1998; Phillipson, 1997; Widdowson, 1994) have questioned the current state of this so-called international asset, i.e. English as a global language, which is governed by few titled English-speaking countries. As one of the earliest critics of the issue of the inner circle's English ownership, Widdowson (1994) holds that no country is entitled to appropri- 
ate English as it is the global language. In a similar vein, Phillipson (1997) asserts that the English language should not only be international but also pivot more on the norms and language authority of English-language learners, i.e. users, than the authority and thus superiority of native speakers and their cultures. Also, Pennycook conceives of English as a worldly language, as well as a world language (Pennycook, 1994). Most permissive of all, Pennycook (1998) maintains that English belongs to whoever chooses to use it. In fact, it could be such similar criticisms, calling for a troubleshooting path toward a fairly inclusive language, that have given rise to ELF as a supple reading of English as a global language, so to speak. Historically, it is to be noted that ELF is commonly considered the byproduct of globalized English, or in Seidlhofer's (2003) words, "ELF is part of the more general phenomenon of 'English as an international language' (EIL) or 'World Englishes'."

Regarding the cultural contents, the current English language materials do not seem to be culturally global in actual practice. This unfair state of English as a global language has markedly been substantiated in literature. For instance, a large number of researchers regard the cultural contents of English textbooks and materials as shallow, alike (Shin et al, 2011; Yuen, 2011), biased (Solhi, 2014), and even unreliable (Forman, 2014). In a similar vein, Jenkins (2007) points out that there are two flaws in the concept of English as a global language: the unavailability of non-native-oriented materials and the false haughty notion of English as a native language recognized as the only genuine English. Even worse, this very unjust current state of English is compounded when it comes to the Kachruvian expanding circle countries, in which English does not have an official status. As for such unjust condition of English in the expanding circle, the state of the English language and culture in Iran could be considered as a case in point. According to Pishghadam and Zabihi's (2012) study in the Iranian EFL context, there is a type of marginalization rooted in the ignorance of the local culture and religion. Similarly, addressing the language users in the same context, Akbari (2008) believes that there is a sense of inferiority among English language learners, due to the ignorance of English language textbook writers about the real lives of the non-native users of English.

To redress the balance in this so-called global language, researchers have made a number of proposals. For instance, McKay (2003a) believes that we should consider English without attaching it to a given culture. One of her suggestions is that we should not draw only on native English-speaking countries for the cultural content of English language materials. On the other hand, extending Kirkpatrick's (2007b) stance on the indigenization of English in the outer circle countries' varieties, Pishghadam and Zabihi (2012: 66) stress the issue of empowering language learners to construct their own local English varieties, a breakthrough which helps them to go above and 
beyond the imitators of native speakers and lets them "become capable of expressing their unique ways of thinking and presenting their local cultures". Drawing on a more moderate, inclusive, and flexible term, the majority of ELF scholars also emphasize such empowerment of the English users in the expanding circle. In fact, most of the advocates of ELF subscribe to the concepts of observed regularities (Seidlhofer, 2009) and community of practice (Cogo, 2012) rather than the traditional terms such as community and variety so as to show the inherently dynamic and diverse nature of ELF. In other words, as Jenkins (2018) holds, these commonly observed features of ELF interactions are so flexible and variable that one cannot pin them down as a variety in the conventional sense. Accordingly, Seidlhofer (2011) argues that we should conceive of ELF as an innovative window opened to English users to be more creative in their use of English. Lastly, subscribing to the right of neologism in the outer circle as well as the expanding circle, Kirkpatrick (2014) elaborates on the different types of cultural encoding made by English users. In fact, it is this very recognition of cultural neologism in the English language which this paper attempts to weigh through the eyes of EFL teachers who are regarded as an authorized point of reference.

\section{Review of the related literature}

English as a global language has witnessed very distinctive status as compared to other languages for two momentous metamorphoses. First, the distinction between the non-native and native speakers of English has been blurred due to the non-native speakers' appropriation of the English language (Swales, 1993; Walker, 2001; Widdowson, 2003). Second, the number of native English speakers has decreased in comparison with that of nonnative speakers (McKay, 2003b; Kivistö, 2005). In fact, this unprecedented status of the English language has brought about a number of hot issues among scholars. These issues are addressed in the following section under four main areas of contention: the global language and power, the global language and culture, the global language and its models, and the global language and its remedies. The contentious area of the global language and power discusses the role of power both in the adoption and maintenance of one language as a global language, as well as the negative byproducts of adopting English as a global language. The contentious area of the global language and culture discusses two common metaphors on the relationship between culture and language, the culture of English as a global language, and an intricate classification of culture. The contentious area of the global language and its models discusses two orthodox models regarding English as a global language and their critiques. The last contentious area of the global language and its remedies discusses a number of flaws in English as a global language and their proposed solutions. 


\subsection{The global language and power}

The very first area of contention concerns the reason behind choosing one language as an international language. Unlike the common optimistic notion which might link such adoption to linguistic factors, Crystal (2003), taking a critical stance, points out to the element of power on the part of the native speakers as the main reason for that adoption. More importantly, he believes this very element of power has always played its unique role for establishing a language of international communication in history. To prove his standpoint, he touches upon Greek and Latin as two ancient languages for international communication in the Middle East and across Europe, respectively. He believes their recognition was not related to the famous intellects such as Plato and Aristotle or any other cultural assets, but it was mainly linked to their armies and power. Not surprisingly, one could imagine that there has been a similar story behind the adoption of English as a global language. Obviously, one should bear in mind that the above fact helps adopt a critical attitude toward the advantageous traditional concept of the native speaker which in turn affects a number of issues such as English ownership, the English language norms-providing circle, and the culture of English.

Not only is power argued to have an influential role in the adoption of an international language, but it is also supposed to play an important role in the so-called maintenance of such a language. As for English, Seidlhofer (2005: 339), for example, believes that "there is still a tendency for native speakers to be regarded as custodians over what is acceptable usage." Evidently, there is also another side to this exclusive supervision of English by its so-called genuine native speakers. In fact, a considerable number of issues could be the byproducts of the monopoly on the English language. To mention a few influential documented cases in literature, we should note that the issues pertaining to an unrecognized identity, a dual attitude, and biased representation are often linked to such exclusive ownership. As for the issue of an unrecognized identity, Norton (1997) argues that the binary division of speakers into native speakers and non-native speakers could hinder learners from enjoying the benefit of English since within this dichotomous framework learners are not regarded as legitimate speakers. Addressing the issue of a dual attitude, Kachru (1992a: 60) highlights the possibility of "linguistic schizophrenia", a term which indicates a big gap between the theoretical understanding and practical implementation of English as a global language. In other words, while all the three Kachruvian circles could theoretically claim and invest in the ownership of English, there seems to be the element of prestige at play in preferring an inner-circle variety as the standard variety to a local type. Lastly, dealing with the issue of biased representation, Jenkins (2007) stresses two major flaws in ELT: first, that non-nativeoriented materials are not available, and, second, that English as a native 
language is often portrayed as the only real English and thus its speakers are often considered the only experts.

\subsection{The global language and culture}

Regarding the second area of contention, it could be useful to touch on the issue of the relationship between culture and language first, and then to address the main topic at hand. Basically, there is a strong bond between language and culture that has given rise to a wealth of metaphors. In fact, these metaphors, by which such close intimacy can be elucidated, are of different types. To mention two common examples, Jiang (2000) points out to the metaphor of language likened as the mirror of culture and that of the iceberg. Whereas the metaphor of the mirror is quite straightforward in depicting language as a thorough picture of culture and the other way around, the metaphor of the iceberg allows us to have slightly different interpretations based on the angle through which the iceberg is observed. According to one prevalent reading of the iceberg metaphor, the small visible portion chiefly points to language elements, while the greater invisible part largely alludes to cultural content (Jiang, 2000). However, the above-mentioned well-established bond between culture and language does not entirely hold true for English as an international language (EIL) and its longed-for offspring English as a Lingua Franca (ELF), as such a tangled association is yet to be carved in stone. In fact, this yet uncharted state of culture becomes more evident due to the dynamic nature of ELF. Suffice it to say, Cogo (2012: 98), stressing this dynamic nature of ELF, holds that ELF "is spoken as a contact language by speakers from varying lingucultural backgrounds, where both the community of speakers and the location can be changing and are often not associated with a specific nation."

To delve into culture per se, various slants and thus varied classifications, depending on the nature of the subject, are brought into play. One of the slants which bears particular relevance to the globalized world is Walker's (2000 : 232) classification into achievement culture, informational culture, and behavioral culture. The behavioral culture, which is of paramount importance in education, falls into three types based on the native's eye: revealed culture, i.e. the bright side of culture; ignored culture, i.e. the often unknown side of culture; and suppressed culture, i.e. the dark side of culture. The crucial point is whether or not non-English speaking countries should introduce the highly characteristic language elements of these three types of their culture, suppressed culture in particular, to ELF.

Importantly, the English language has materially affected the cultures of ELF users. More specifically, although some scholars (e.g. Dörnyei, 2005) believe that English as a global language is to support globalized citizen 
identity rather than to challenge the learners' identity, there is a large number of critics who are concerned about the negative effects of such a so-called benevolent and unbiased global language (e.g. Akbari, 2008; Pishghadam \& Zabihi, 2012; Solhi, 2014).

\subsection{The global language and its models}

The third area of contention is concerned with English as a global language and its proposed models. These models aim to categorize different countries and ELF users based on the spread of English in different countries and proficiency in English as an international language, respectively. To shed light on the different types of countries pivoting on the spread of English, Kachru's (1985) orthodox classification often comes in handy. According to this often-quoted taxonomy, countries across the world fall into three circles as far as the expansion of English is concerned: the inner circle, outer circle, and expanding circle. The countries in the inner circle are those whose native language is English such as America, England, and Canada. The countries belonging to the outer circle are those whose native language is not English but they have recognized English as an official language such as India, Pakistan and Indonesia. Lastly, the countries classified within the expanding circle are those in which English is neither their native language nor official language, such as Iran, Italy, and Egypt. Moreover, Kachru (1992b) elaborates on the different roles of these countries in the spread of English. According to the assumed roles, the inner circle reigns supreme by being normproviding and the outer circle is granted to be as norm-developing, whereas the expanding circle has to content itself with a norm-dependent role (Kachru, 1992b).

Leveling their criticisms at Kachru's (1985) concentric model as a point of reference for the current expansion of the English language, a large number of critics call this model into question (Bruthiaux, 2003; Kirkpatrick, 2007a; Hülmbauer et al, 2008; Park \& Wee, 2009). Kirkpatrick (2007a), for example, contends that Kachru's (1985) framework of the outer and expanding circle countries is not impartial as it pivots on a native-speaker model of English. Hülmbauer et al. (2008: 27) argue that the tendency of the Kachruvian circles toward a native speaker model is flawed for two main reasons. First, "given the fact that the non-native speakers now outnumber the native speakers by many times, it is highly questionable whether the centrality of the native speakers is still justified". Second, applying the label norm-dependent to the expanding circle "ignores the emergent nature of ELF, whereby its users appropriate the language and shape it to their needs" (ibid, 28). Likewise, criticizing the status quo of English as a global language, McKay (2003b) holds that the cultural basis of English teaching has been mainly concerned with the inner circle countries, a fact which runs contrary to the World Eng- 
lishes movement. McKay (2002) also maintains that English as a global language should be informed by both the inner and outer circles of English varieties. Going one step further, Seidlhofer (2003) and Higgins (2003) assert that countries in the expanding circle could also join the mainstream circle owing to the rapid spread of English. Lastly, to authorize the ownership of English in the other two circles, Hall (2000: 6) argues for the "local ownership of English."

In an attempt to form a neutral basis for defining different English varieties regardless of the native language of English speakers, Modiano (1999) proposes a conceptual model of English speakers pivoting on proficiency in the English language. This centripetal model consists of three circles. As far as international communication is concerned, the inner-most circle encompasses competent English users. The second circle refers to English users who are not proficient in English as a global lingua franca, but otherwise they could be proficient. More specifically, this circle is comprised of five varieties of English: American, British, other native varieties, local varieties like Indian English, and foreign varieties. The third circle includes incompetent English users. The model above enjoys the benefit of an international underpinning, a quality which has received worldwide scholarly attention. Despite having several advantages over the Kachruvian model such as having an international inner circle (Kivistö, 2005), Modiano's model could also be challenged on its so-called ideologically neutral concept of intelligibility (Rajagopalan, 2010) as well as its very yardstick for labeling English users from different verities as either internationally comprehensible or incomprehensible (Earling, 2005).

\subsection{The global language and its remedies}

The last area of contention has been addressed in a considerable number of studies; each study has focused on one specific aspect of this area of contention. As for the current educational state of English as a global language, Kasaian and Subbakrishna hold "there is a growing tendency in many parts of the world to dissociate the ELT profession from the native speakers' norms of linguistic accuracy and social appropriateness" (Kasaian \& Subbakrishna, 2011: 230). Similarly, Phillipson, who calls the state of one English language into question, subscribes to several Englishes as a possible path to the decentralization of ELT (Phillipson, 1992: 197). There are, as Pennycook (1994) points out, problems with the total efficiency of the Western as well as Asian ELT, too. To resolve the above obstacles concerning the ELT field, Pennycook (1994: 64) proposes that "perhaps language - and particularly English as an international language - should also be replaced by a vision of powerful discursive formations globally and strategically employed". In a similar vein, Akbari (2008) asserts that, since most communications in Eng- 
lish today are between non-native speakers, English users do not have to stick to the Anglo-American culture. Last, but by no means least, reviewing a host of studies on teaching English in Iran as a country in the expanding circle, Pishghadam and Zabihi assert that:

...we need to take a look beyond the current state of TEFL in Iran and into the future, with an emphasis on the importance of including the local specificities of the Iranian culture and religion, coming up with a new notion, i.e. Iranian TEFL, which reflects not only the Iranian people's Islamic thesaurus, as part of their religious identity, but also their cultural, social, and historical perspectives. (2012: 66)

\section{The purpose of the study and research questions}

This study was aimed at exploring the attitude of the EFL teachers toward the right of cultural neologism in ELF. More specifically, the attitude of the Iranian teachers, the indirect construct, was considered as a major indicator for evaluating the norm-overriding role of English language teachers in Iran, as a country in the expanding circle. To this end, the researchers designed a questionnaire in the three phases of identification, classification, and selection. Next, the questionnaire was administered to a number of Iranian teachers of English with a wide range of teaching experience. The teachers further fell into one of the five pre-designed experience-related categories: less than five years, less than ten years, less than fifteen years, less than twenty years, and twenty or over twenty years. To find out whether or not the teachers were homogeneous in their attitudes, all five categories of the teachers and their plausible integrated binary categories, i.e. less than ten years versus ten or more than ten years, and less than fifteen years versus fifteen or more than fifteen years, were compared. As for the comparison between the five categories, separated from one another by the time-gap of five years, a five way ANOVA was run, indicating no significant difference between the five groups. As for the comparison between each of the two plausible binary categories, two independent t-tests were carried out which only indicated a significant difference between the attitudes of the teacher with less than fifteen years of experience and those of the teachers with fifteen and more than fifteen years of experience. In short, the above set of comparisons eventually gave rise to two distinctive groups, and the participants fell into two groups: one with 79 veteran teachers who had at least 15 years of teaching experience and another one with 272 non-veteran ones who had less than 15 years of teaching experience. As a result, the researchers found the opportunity to explore the research questions twofold: quantitatively and qualitatively. The quantitative slant was supposed to find out whether or not the overall findings would reveal the teachers' attitude toward the right of cultural neologism in ELF and to what extent the length of experience would 
come in, if at all. On the other hand, the qualitative lens was aimed to identify the order of priorities regarding the various aspects of culture, as well as to discern any noticeable patterns gained from comparing and contrasting the two groups.

\section{Data collection}

A questionnaire on the cultural attitude of Iranian teachers of English, as mentioned earlier, was the main means of the data collection. This questionnaire was progressively made up over the three main phases of data analysis in an inductive fashion. Below are the brief descriptions of the three phases of identification, classification, and selection, plus the description of the participants and the method of obtaining the data.

\subsection{The first phase: identification}

The researchers looked up all the entries of a monolingual Persian dictionary, named Farhang Moaaser Farsi (Sadri Afshar et al, 2002), so as to find any probable Persian culture-specific words. In the first attempt, over a hundred words were found. In the second attempt, all the words went through a more detailed examination so as to cross out culturally insignificant words, words only used in a set phrase like an idiom, or words having an acceptable equivalent in English. After the second examination, ninetyeight highly culture-specific Persian words were identified to be eligible (See Appendix A for all the categorized culture-specific words).

\subsection{The second phase: classification}

Looking into the eligible words, the researchers came up with twelve cultural aspects and classified the words under their corresponding aspects, dubbed as: place, relation, title, profession, ritual, civilized product, occasion, object, belief, state, trait, and superstition. Next, given the three elements of the degree of untranslatability, the frequency of use, and cultural distinctiveness, these culture-specific words were ranked by three English language teachers having ten-plus years of teaching experience. Finally, from among each group, one word was qualified as the prime example of its corresponding aspect. In total, twelve words of choice for the most significant candidates of cultural-specific words were picked out. 


\subsection{The third phase: selection}

Each culture-specific word was put into one directional question so as to depict the respondents' attitude toward the prospective contribution of their culture-specific word to ELF on a five-point Likert scale. Overall, the twelve questions, symbolizing the twelve neglected aspects of the Persian culture, were made to fit in with the global culture of ELF. Importantly, the length of teaching experience was regarded as a variable. Additionally, the respondents were asked to write some information such as their full names, age, length of teaching experience, main place of teaching so as to control any probable moderator variable in the analysis (See Appendix B for the questionnaire).

It is worth mentioning that the participants of this study included 351 English language teachers ranging from a budding teacher who had only been teaching English to a private student for some months to a highly experienced teacher who had been teaching English for more than three decades. Due to the need for a large number of participants for these kinds of studies, the informants were chosen either from the cyber groups on Telegram or university groups through convenience and snowball sampling, respectively. Lastly, although few questionnaires were filled out on paper in the presence of one of the researchers, most of the questionnaires were administered to the respondents via the Internet.

\section{Results and discussion}

\subsection{The findings focusing on all the participants}

In what follows, the main findings, translated into three tables, are progressively described and explained; meanwhile, the answers to the questions of the study are touched on. To begin with, the degrees of agreement on the twelve items as well as the length of teaching experience pointed to a host of salient facts and figures in connection with cultural aspects (see Table 1). As for the answer to the main questions of the study, i.e. the right of cultural neologism in ELF, the result of the analysis of the questionnaire proved that the majority of the respondents agreed on ten out of the twelve Persian culture-specific words, albeit to different extents, to find their ways into English. Based on the mean rating scores for each of the aspects, the degrees of agreement on the prospective words ranged from $55 \%$ to $82 \%$, while $60 \%$ was calculated as the accepted cut-off point for agreement. The highest agreement went to the word Yalda pertaining to the aspect of occasion. The other highly-agreed words turned out to be Zoor Khaneh and Korsi belonging to the aspects of place and object, respectively. It is worth noting that while the other aspects received agreement with a narrow margin, the least 
agreement with a considerable margin went to the word Saq-e Siah (black palate) concerning the aspect of superstition. More specifically, the following rank order of the significance of the prospective words could be drawn based on all the respondents' preferences.

Table 1: The rank and percentage of the persian culture-specific words based on their significance.

\begin{tabular}{|c|c|c|c|}
\hline Rank & Aspect of culture & Word & $\begin{array}{l}\text { percentage of } \\
\text { total approval }\end{array}$ \\
\hline $\begin{array}{l}\text { Total } \\
\text { rank }\end{array}$ & Aspect of culture & word & $\begin{array}{l}\text { All the partici- } \\
\text { pants }\end{array}$ \\
\hline 1 & Occasion & Yalda & 81.823 \\
\hline 2 & Place & $\begin{array}{l}\text { Zoor khaneh (house of } \\
\text { strength) }\end{array}$ & 72.934 \\
\hline 3 & Object & korsi & 72.535 \\
\hline 4 & Relation & mahram & 69.572 \\
\hline 5 & Profession & hakim & 67.122 \\
\hline 6 & Title & allameh & 63.076 \\
\hline 7 & State & namus & 61.595 \\
\hline 8 & Trait & gheirat & 61.310 \\
\hline 9 & Civilized product & resaleh & 60.512 \\
\hline 10 & Belief & namak gir (Salt-bound) & 60.056 \\
\hline 11 & Ritual & khastegari & 59.088 \\
\hline 12 & Superstition & saq-e siah (Black palate) & 55.384 \\
\hline
\end{tabular}

As can be seen, Yalda and zoorkhaneh (house of strength) under the aspects of occasion and place were ranked as the most suitable words to make their way into English. The reason behind these choices could partly be explained through the metaphor of culture as an iceberg. According to this metaphor, the deepest layers of culture embrace those intangible aspects which are invisible to outsiders, whereas the top layers embody a more tangible aspect. In other words, superstition, belief and trait as the prime examples of the intangible aspects of culture are among the deepest layer of culture. It also implies that these invisible aspects are the most mystified elements of the Iranian culture which might easily go unnoticed. On the other hand, the words gheirat, namak gir, and saq-e siah, respectively corresponding to the 
aspects of trait, belief, and superstition, were identified as the lowest ranks in terms of importance. The justification for these ranks cannot only be made through the metaphor of culture as an iceberg, as these aspects form the central part of the iceberg, not the upper part. For a convincing explanation, especially regarding the most radical word saq-e siah, one needs to attend to Walker's (2000) concept of suppressed culture. Evidently, the word saq-e siah, gaining the least acceptance, should definitely be classified under suppressed culture, a category of culture which refers to the side of culture that a native is reluctant to introduce to outsiders (Walker, 2000). Additionally, the linguistic aspects of these words could also be at work, too. In fact, these two words are a special type of compound words whose meanings may not be predictable from their individual words. In other words, they sound to be idiomatic, a point which might color their literal translations. Besides, the original forms of these words, that is to say, their transliterations might not sound natural to English language teachers.

The results of the other categories are in keeping with the metaphor of culture as an iceberg since words belonging to the other categories in the central parts, including relationship, civilized product, title, and occasion, were ranked from the highest categories of concept and quality to the lowest categories of state and belief.

\subsection{The findings comparing the two divided groups of the partici- pants}

In search of spotting any probable patterns of note between the answers and the respondents having different lengths of teaching experience, the respondents were numerously compared with each other in terms of their different lengths of experience. The above exploration eventually gave rise to two distinct groups and the participants fell into the two groups of 79 veteran teachers who had at least 15 years of teaching experience and 272 non-veteran ones who had less than 15 years of teaching experience. Then an independent t-test was run and its results showed a significant difference between the ranks leaning toward the veteran group as follows: the $t$-value, 2.127 , in the independent $t$-test exceeded the $t$-critical, 2 , at the level of significance of .05

Next, the orders of the ranks in the two groups were microscopically juxtaposed to see whether or not there were any differences in their priorities and if so, what such differences point to. 
Table 2: The comparison of the ranks of the words between the two groups.

\begin{tabular}{|c|c|c|c|c|c|c|}
\hline $\begin{array}{l}\text { Total } \\
\text { Rank }\end{array}$ & $\begin{array}{l}\text { Aspect of } \\
\text { culture }\end{array}$ & Word & \multicolumn{2}{|c|}{ Veteran Group } & \multicolumn{2}{|c|}{$\begin{array}{l}\text { Nonveteran } \\
\text { Group }\end{array}$} \\
\hline 1 & Occasion & Yalda & 1 & 79.49 & 1 & 82.50 \\
\hline 2 & Place & $\begin{array}{l}\text { Zoor khaneh } \\
\text { (house of } \\
\text { strength) }\end{array}$ & 3 & 75.44 & 2 & 72.20 \\
\hline 3 & Object & korsi & 2 & 76.20 & 3 & 71.47 \\
\hline 4 & Relation & mahram & 4 & 74.93 & 4 & 68.01 \\
\hline 5 & Profession & hakim & 5 & 69.62 & 5 & 66.39 \\
\hline 6 & Title & allameh & 10 & 65.31 & 6 & 62.42 \\
\hline 7 & State & namus & 6 & 68.86 & 8 & 59.48 \\
\hline 8 & Trait & gheirat & 11 & 64.05 & 7 & 60.51 \\
\hline 9 & $\begin{array}{l}\text { Civilized } \\
\text { product }\end{array}$ & resaleh & 8 & 66.58 & 9 & 58.75 \\
\hline 10 & Belief & $\begin{array}{l}\text { namak gir } \\
\text { (Salt-bound) }\end{array}$ & 9 & 66.32 & 10 & 58.23 \\
\hline 11 & Ritual & khastegari & 7 & 67.34 & 11 & 56.69 \\
\hline 12 & Superstition & $\begin{array}{l}\text { saq-e siah } \\
\text { (Black palate) }\end{array}$ & 12 & 57.72 & 12 & 54.70 \\
\hline
\end{tabular}

As can be seen in Table 2, although both groups shared quite a similar pattern regarding the first five aspects, they considerably differed for the other aspects, except for the last one. The widest margin in the comparison between the ranks belonged to the three aspects of title, trait, and ritual. In fact, while the non-veteran group laid far more stress on the aspect of title and trait than the veteran group did, the veteran group gravitated much more toward the aspect of ritual than the non-veteran group did. Not surprisingly, the aspect of superstition was the least conspicuous layer as both groups similarly placed it at the bottom of their priority lists.

The justification one can make is quite straightforward: the first five items concern the more visible aspects of the iceberg, while the other six aspects mainly involve more invisible aspects. It is worthy of note that both groups showed their similar certain reservations regarding the last aspect, i.e. superstition. This very aspect of culture, in spite of its deep location in the 
iceberg, reflects the controversially dark side of culture, a point which might cause the native speakers to be reserved. The most distinguishing aspects which include state, ritual, civilized product, belief, title, and trait could clearly point to the different lenses these two types of teachers wear. In fact, while the veteran group adhered to the more collective and invisible aspects of culture such as state and ritual, the non-veteran group preferred the more individualized and less invisible aspects of culture such as title and trait. Additionally, as can be seen, the veteran group showed considerably smaller fluctuations in their evaluation of the twelve aspects than the non-veteran group did. More specifically, their comparison indicates that the veteran group's agreement ranged from $57 \%$ to $79 \%$, while the non-veteran group's agreement ranged from $54 \%$ to $82 \%$.

\section{Conclusion}

All in all, the attitudes of the Iranian teachers of English implied that right of cultural neologism in ELF is rightfully felt in the expanding circle and the approval of ten out of the twelve eligible words, to different degrees, should be regarded as a case in point. In effect, this study provides evidence that the majority of the Iranian teachers of English, despite showing their approval in different degrees, display a palpable sense of shared ownership on English as a lingua franca. Taking such a patriotic attitude on the part of the English language teachers, the veteran group in particular, one could pose this legitimate question: why have such cultural exigencies not already been recognized? This thorny question could be partially answered by drawing on the term linguistic schizophrenia (Kachru, 1992a), a concept which suggests that there is a double standard in favor of so-called Standard English over local varieties and, by extension, local words. In other words, although the majority of the Iranian teachers of English do echo Widdowson's (1994) landmark assertion concerning the right for all the countries across the globe to own English, they have reservations sticking to it in practice by reason of high prestige attached to a standard variety. This very element of prestige could come from the orientation of English language materials, which Pennycook (1994) warns about.

Seemingly over the long term, the majority of the veteran teachers have come to sharpen their cultural sensitivity through their dual roles as both an English language teacher and English language encoder. In fact, not only do they teach the English language through the textbooks, but also they creatively translate, or better to say, encode their native concepts or Persian words into English on demand. Clearly, this latter usage of English, i.e. cultural encoding (Kirkpatrick 2014), helps the veteran teachers become aware of the components of what they encode, a fact which pushes them to notice 
the gaps in their encodings. In other words, they have a favorable opportunity to identify what cultural lexicons should be revived in their specific ELF community of practice so that one can portray the true image of their own culture. In so doing, they show a prime example of the fluid and dynamic nature of ELF, subscribed to by its staunch advocates Seidlhofer, 2009; Cogo, 2012), as well as the creative quality of ELF (Seidlhofer, 2011). It could also be inferred that the turning point in cultural sensitivity comes after 15 years of teaching experience, a period which can turn teachers into the cultural architects of language, so to speak.

This study also suggests the countries in the expanding circle should virtually follow the route the countries in the outer cycle need to take. According to a considerable number of scholars (e.g. Kachru, 1992b; Kirkpatrick, $2007 \mathrm{~b}$ ), the countries in the outer circle could establish their new variety of English as a legitimate one so as to meet their own culture-specific needs and to represent their own culture to the world. It is also felt that the countries in the expanding circle should take a similar path. In effect, if the idea of developing a local variety of English for the countries in the expanding circle is far-fetched, they should at least attempt to have the significant culture-specific words of their own language find their way into ELF. Suffice it to say, Hülmbauer et al. (2008: 28) state ELF "users appropriate the language and shape it to their needs". According to this very study, one way to establish such cultural lexicons could be through the act of neologism endorsed by EFL teachers. To this end, EFL teachers can set a good example to English language learners who most probably account for the main body of ELF users. Although there is still tendency for English-speaking countries in the inner circle, mostly America and England, to supervise the English language (e.g. Seidlhofer, 2005), ELF users, who account for the majority of English interactions, should be entitled to voice their words. Obviously, only through a fair distribution of voice, non-native English-speaking countries, especially those in the expanding circle, can appropriately present their culture to the world using ELF. This daring stance for the countries in the expanding circle is in consonant with what Akbari (2008) states on the need for a divergence from the Anglo-American culture since most communications in English today are between non-native speakers. In other words, it is time for the silent majority, i.e. non-native English speakers, to be granted with a norm-overriding role to voice their words.

As another implication for the main finding of this study, one could point to a serious gap in Modiano's (1999) model. In his model, the language elements, which the English language users of the inner-most circle must be versed in, do not include cultural features specific to a given culture, as such features might be incomprehensible to other competent EIL users. However, there seem to be two flaws in this reading of EIL. First, the cultural identity 
of non-native English speakers is ignored for the sake of alleged incomprehensibility. Second, the fluid and dynamic aspects of language, which could greatly facilitate comprehension (Cogo, 2012), are not taken into account. Third, the culture of English as a global language has already been informed by the inner circle countries (Kachru, 1992b), a fact which requires undergoing marked changes to be international in the real sense of the word.

Admittedly, there are several limitations to the present study that serve as the foundation for further research. First, the researchers did not address the issue of the comparison between resident versus non-resident teachers in English-speaking country, a point which was not explored due to the low ratio of the resident teachers to non-resident ones. Second, the issue of bilingualism in English and Persian, which might go hand in hand with the element of the length of teaching experience in regard of cultural sensitivity, was not taken into account. Lastly, though the selected words were chosen in a complicated process through the views of three experienced English teachers as the judges, the impact of compound versus non-compound words on the respondents' attitude was not taken into consideration. Other studies could be carried out controlling such linguistic elements. Of interest is to gather and analyze data among the three groups of non-compound nouns, compound nouns, and expressions to see if similar findings will be replicated.

\section{References}

Akbari, Ramin (2008). Transforming lives: introducing critical pedagogy into ELT classrooms. ELT Journal 62(3) 276-283. https:// doi.org/10.1093/elt/ccn025

Bruthiaux, Paul (2003). Squaring the circles: Issues in modelling English worldwide. International Journal of Applied Linguistics 13(2): 159-178. https://doi.org/10.1111/1473-4192.00042

Cogo, Alessia (2012). English as a lingua franca: concepts, use, and implications. ELT Journal 66(1): 97-105. https://doi.org/10.1093/elt/ccr069

Crystal, David (2003). English as a global language (2nd ed.). Cambridge: Cambridge University Press.

Dörnyei, Zoltán (2005). The psychology of the language learner. Mahwah, NJ: Lawrence Erlbaum.

Erling, Elizabeth (2005). The many names of English: A discussion of the variety of labels given to the language in its worldwide role. English Today 21(1): 40-44. https://doi.org/10.1017/S0266078405001094

Forman, Ross (2014). How local teachers respond to the culture and language of a global English as a foreign language textbook. Language, Culture, and Curriculum 27(1): 72-88. https:/ / doi.org/: 10.1080/07908318.2013.868473

Gilmore, Alex (2007). Authentic materials and authenticity in foreign language learning. Language Teaching 40(2): 97-118.

https://doi.org/10.1017/S0261444807004144 
Hall, Graham (2000). Local approaches to Critical Pedagogy: An Investigation into the Dilemmas Raised by Critical Approaches to ELT (CRILE Working Paper No. 48). Lancaster, Lancashire, England: Lancaster University, Linguistics Department. Retrieved from http://www.ling.lancs.uk/grups/crile/working papers.htm

Higgins, Christina (2003). "Ownership" of English in the outer circle: An alternative to the NS-NNS dichotomy. TESOL Quarterly 37(4): 615-644. https://doi.org/10.2307/3588215

Hülmbauer, Cornelia, Heike Böhringer, Barbara Seidlhofer (2008). Introducing English as a lingua franca (ELF): Precursor and partner in intercultural communication. Cali, Chantal, Martin Stegu, Eva Vetter, eds., Enseigner - apprendre - utiliser le francais langue internationale en Europe aujourd'hui: pour une perspective comparatiste. Synergies Europe $n^{\circ} 3,25-36$. Retreived from http://ressourcescla.univfcomte.fr/gerflint/Europe3/hulmbauer.pdf

Jenkins, Jennifer (2007). English as a Lingua Franca: Attitude and identity. New York: Oxford University Press.

Jenkins, Jennifer (2018). Trouble with English? In Kelly, Michael, ed., Language after Brexit: How the UK Speaks to the World. Cham: Palgrave Macmillan/Springer, 25-34. http://dx.doi.org/10.1007/978-3-319-65169-9_3

Jiang, Wenying (2000). The relationship between culture and language. ELT Journal 54(4): 328--334. https://doi.org/10.1093/elt/54.4.328

Kachru, Braj Bihari (1985). Standards, codification and sociolinguistic realism: The English Language in the outer circle. Quirk, Randolph, Henry Widdowson, eds., English in the world: Teaching and Learning the Language and Literature. Cambridge: Cambridge University Press, 11-30.

Kachru, Braj Bihari (1992a). Models for non-native Englishes. Braj Bihari Kachru, ed. The other tongue: English across cultures (2nd ed.). Urbana: University of Illinois Press, 48-74.

Kachru, Braj Bihari (1992b). World Englishes: approaches, issues and resources. Language Teaching 25(1): 1-14. https:/ / doi.org/10.1017/S0261444800006583

Kasaian, Seyed Ahmad, Rangaswamy Subbakrishna (2011). Iranian parents' resistance to incompatible aspects of Western culture: Implications for ELT Material Development. CCSE English Language 4(1): 230-239.

https://doi.org/10.5539/elt.v4n1p230

Kirkpatrick, Andy (2007a ). Setting attainable and appropriate English language targets in multilingual settings: A case for Hong Kong. International Journal of Applied Linguistics 17(3): 376-391.

https://doi.org/10.1111/j.1473-4192.2007.00170.x

Kirkpatrick, Andy (2007b). World Englishes: Implications for International Communication and English Language Teaching. Cambridge: Cambridge University Press.

Kirkpatrick, Andy (2014). English in Southeast Asia: Pedagogical and policy implications. World Englishes 33(4): 426-438. http:/ / dx.doi.org/10.1111/weng.12105

Kivistö, Anne (2005). Accents of English as a Lingua Franca: A Study of Finnish Textbooks (Unpublished Master's thesis). University of Tampere, Finland.

McKay, Sandra Lee (2002). Teaching English as an International Language: Rethinking Goals and Approaches. Oxford: Oxford University Press.

McKay, Sandra Lee (2003a). Teaching English as an International Language: The Chilean context. ELT Journal 57(2): 139-148. 
https://doi.org/10.1093/elt/57.2.139

McKay, Sandra Lee (2003b). Toward an appropriate EIL pedagogy: Re-examining common ELT assumptions. International Journal of Applied Linguistics 13(1): 122. https:// doi.org/10.1111/1473-4192.00035

Modiano, Marko (1999). International English in the global village. English Today 15(2): 22-28. https://doi.org/10.1017/S026607840001083X

Norton, Bonny (1997). Language, identity, and the ownership of English. TESOL Quarterly 31(3): 409-429. https:// doi.org/10.2307/3587831

Park, Joseph Sung-Yul, Lionel Wee (2009). The three circles redux: A markettheoretic perspective on World Englishes. Applied Linguistics 30(3): 389-406. https://doi.org/10.1093/applin/amp008

Pennycook, Alastair (1994). The Cultural Politics of English as an International Language. London: Longman.

Pennycook, Alastair (1998). English and the Discourses of Colonialism. London: Routledge.

Phillipson, Robert (1992). Linguistic Imperialism. Oxford, UK: Oxford University Press.

Phillipson, Robert (1997). Realities and myths of linguistic imperialism. Journal of Multilingual and Multicultural Development 18(3): 238-248. https://doi.org/10.1080/01434639708666317

Pishghadam, Reza, Reza Zabihi (2012). Crossing the threshold of Iranian TEFL. Applied Research in English 1(1): 57-71.

Rajagopalan, Kanavillil (2010). The soft ideological underbelly of the notion of intelligibility in discussions about "World Englishes". Applied Linguistics 31(3): 465-470. https://doi.org/10.1093/applin/amq014

Sadri Afshar, Gholam Hossein, Nasrin Hakami, Nastaran Hakami (2002). Farhang Moaaser Farsi [The Contemporary Dictionary of Persian]. (4th ed.). Tehran: Farhang Moaaser Print.

Seidlhofer, Barbara (2003). A Concept of International English and Related Issues: From "Real English" to "Realistic English". Strasbourg: Council of Europe. Retrieved from http://www.coe.int/t/dg4/linguistic/source/seidlhoferen.pdf.

Seidlhofer, Barbara (2005). English as a lingua franca. ELT Journal 59(4): 339-341. https://dx.doi.org/10.1093/elt/cci064

Seidlhofer, Barbara (2009). Common ground and different realities: World Englishes and English as a lingua franca. World Englishes 28(2): 236-245.

Seidlhofer, Barbara (2011). Understanding English as a Lingua Franca. Oxford: Oxford University Press.

Shin, Jeeyoung, Zohreh Eslami, Wen-Chun Chen (2011). Presentation of local and international culture in current international English-language teaching textbooks. Language, Culture and Curriculum 24(3): 253-268.

https://doi.org/10.1080/07908318.2011.614694

Solhi, Mehdi (2014). Calling for English for specific cultures-based coursebooks in English as an international language era. International Journal of English Language Education 2(2): 279-294. https://doi.org/: 10.5296/ijele.v2i2.6619

Swales, John (1993). The English language and its teachers: Thoughts past, present and future. ELT Journal 47(4): 283-291. https://doi.org/10.7575/aiac.ijels.v.5n.1p.78

Walker, Galal (2000). Performed culture: Learning to participate in another culture. Richard, Lambert, Elana Shohamy, eds., Language Policy and Pedagogy: Essays 
in Honor of A. Ronald Walton. Amsterdam/Philadelphia: John Benjamins, 221236.

Walker, Robin (2001). International intelligibility. English Teaching Professional 21: 1013.

Widdowson, H. G. (1994). The ownership of English. TESOL Quarterly 28(2): 377-388. https://doi.org/10.2307/3587438/full

Widdowson, H.G. (2003). Defining Issues in English Language Teaching. Oxford: Oxford University Press.

Xiao-yi, Li (2008). Influence of English as an international language on cultural teaching. Sino-US English Teaching 5(4): 29-34.

Yuen, Ka-Ming (2011). The representation of foreign cultures in English textbooks. ELT Forum 65(4): 458-466. https://doi.org/10.1093/elt/ccq089

\section{Authors' addresses:}

Esmat Babaii

Kharazmi University

43 South Mofatteh Avene,

Tehran, Iran

E-mail: babai@khu.ac.ir

Mahmood Reza Atai

Kharazmi University

43 South Mofatteh Avene,

Tehran, Iran

E-mail: mahmood.atai@gmail.com

Abbas Parsazadeh

Kharazmi University

43 South Mofatteh Avene,

Tehran, Iran

E-mail: timcheh2@gmail.com

Received: June 13, 2019

Accepted for publication: September 27, 2019 


\section{Appendix A}

All the categorized culture-specific words

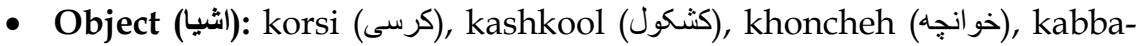

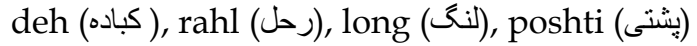

-

Place (مكان): zoorkhaneh (زورخان) (خانه), saqqakhaneh (سقاخانه) , maktabkhane (مكتب خانه) , zarih (ضريح) (ركانه) , qadamgah (قدمشاه), hosseiniyeh (حسينية), tekiyeh (تكيه)

Title (عنوان) : allameh (علامه), kad-

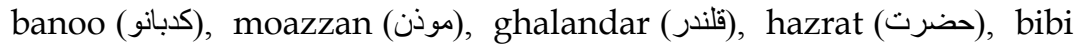

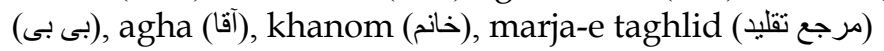

Profession (حرفه): hakim (حكيم), motreb (نطرب), naqqal (نقال), haji firooz (ساجى فيروز), saqi (ساقى), ayyar (عبار)

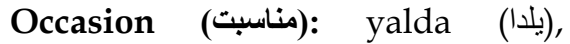
nowrooz (نوروز), sizdah bedar (سيزده بدر), ashoora (عنور) (عانشور)), tasooa

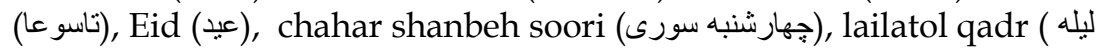
(القدر (ليله الرغايب), lailatyol raghaeb dahvol arz (دهو الارض)

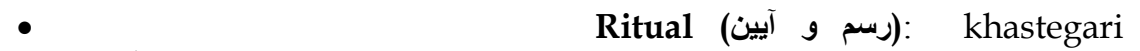

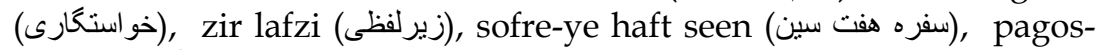

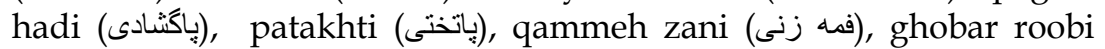

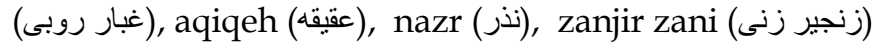

$\bullet$ resale (رساله), faal (فال), fatwa (فنوال)

\section{Civilized product (دستاورد فرهنىى):}

Belief (باور): namus (ناموس), aaq

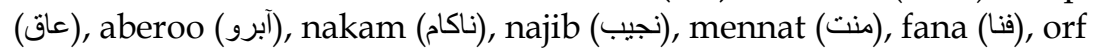

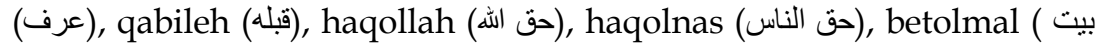

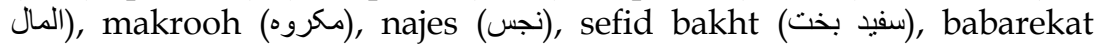
(بابركت), bibarekat (بى بركت), siyah bakht (سياه بخت)

\section{-}

Relation (رابطه): mahram (محرم), re-

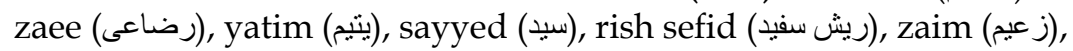
gis sefid (كيس سفيد)

Trait (غصيصد): gheirat (غيرت), zohd

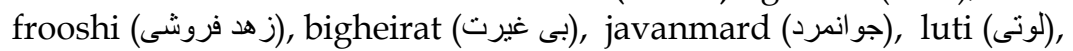

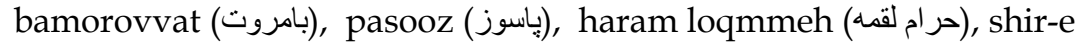

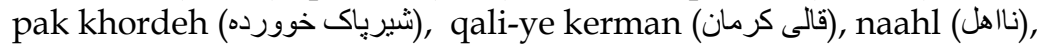
rend (رن)

Superstition (خرافات): saq-e siah ( سقات (خياه), khosh roozi (خوش روزى), khosh qadam (خوش قدم), bad qadam (خرى) 


\section{- $\quad$ State (حالت): namak gir (همى كير),} cheshm berah (جشم بر اه), (جشم انتظار), kalanjar (هلنجار), kadkhoda maneshi (كدخدامنشى) 


\section{Appendix B}

The questionnaire on teachers' attitude toward cultural neologism in English as a Lingua Franca (ELF)

English as an international language needs to represent an international culture. Given the fact that the relation between language and culture is intertwined, English should be used to convey important, common, and distinctive concepts from other cultures. This questionnaire is designed to find out the attitude of the Iranian teachers of English on a number of highly Persian culture-specific items as prospective English words. Please fill out the following questionnaire through circling (or highlighting) the item which best describes whether you agree or disagree with each statement.

$\mathbf{S A}=$ Strongly Agree, $\mathbf{A}=$ Agree, $\mathbf{N}=$ Neither agree nor disagree, $\mathbf{D}=$ Disagree, $\mathrm{SD}=$ Strongly Disagree

Full Name:

Age:

Major and Degree:

Length of Teaching Experience:

Main Place of Teaching: Institutes schools universities

Residence in an English-Speaking Country (if so, what country and how long?):

I think if English is really an global language,

1. The Iranian users of English should be encouraged to let their common, distinctive, and important culture word zoorkhaneh or its literal translation e.g. a house of strength, find its way into English so as to avoid its long and tentative English equivalents such as a traditional Iranian sports gym.
SD
$\mathrm{D}$
$\mathrm{N}$
A
SA

2. The Iranian users of English should be encouraged to let their common, distinctive, and important culture word mahram find its way into English so as to avoid its long and tentative English equivalents such as a close relative of the opposite sex in Islam.
SD
D
$\mathrm{N}$
A
SA

3. The Iranian users of English should be encouraged to let their common, distinctive, and important culture word allameh find its way into English so as to avoid its long and tentative English equivalents such as an honorific title for a widely and profoundly knowledgeable person. 

SD
$\mathrm{D}$
$\mathrm{N}$
A
SA

4. The Iranian users of English should be encouraged to let their common, distinctive, and important culture word hakim find its way into English so as to avoid its long and tentative English equivalents such as a traditional Muslim doctor.
SD
$\mathrm{D}$
$\mathrm{N}$
A
SA

5. The Iranian users of English should be encouraged to let their common, distinctive, and important culture word khastegari find its way into English so as to avoid its long and tentative English equivalents such as an Iranian-style pre-marriage meeting.
SD
D
$\mathrm{N}$
A
SA

6. The Iranian users of English should be encouraged to let their common, distinctive, and important culture word Resaleh find its way into English so as to avoid its long and tentative English equivalents such a book of Islamic edicts by a grand cleric.
SD
D
$\mathrm{N}$
A
SA

7. The Iranian users of English should be encouraged to let their common, distinctive, and important culture word Yalda find its way into English so as to avoid its long and tentative English equivalents such as the longest night of the year.
SD
D
$\mathrm{N}$
A
SA

8. The Iranian users of English should be encouraged to let their common, distinctive, and important culture word korsi find its way into English so as to avoid its long and tentative English equivalents such as a traditional Iranian foot stove.
SD
D
$\mathrm{N}$
A
SA

9. The Iranian users of English should be encouraged to let their common, distinctive, and important culture word namus find its way into English so as to avoid its long and tentative English equivalents such as a man's female family members whom he is obliged to respect and protect.

$\begin{array}{lllll}\text { SD } & \text { D } & \text { N } & \text { A }\end{array}$

10. The Iranian users of English should be encouraged to let their common, distinctive, and important culture word namak gir or its literal translation e.g. salt-taken, find its way into English so as to avoid its long and tentative English equivalents such as bound by ties of hospitality.
SD
$\mathrm{D}$
$\mathrm{N}$
A
SA

11. The Iranian users of English should be encouraged to let their common, distinctive, and important culture word gheirat find its way into English so as to avoid its long and tentative English equivalents 
such as intense honor attached to a man's protection for and modesty of his female family members.

$\begin{array}{lllll}\text { SD } & \text { D } & \text { N } & \text { A } & \text { SA }\end{array}$

12. The Iranian users of English should be encouraged to let their common, distinctive, and important culture word sagh-e siah or its literal translation, e.g. black palate, find its way into English so as to avoid its long and tentative English equivalents such as a regular illomened speaker.
$\mathrm{SD}$
D
$\mathrm{N}$
A
SA

If you have any comments or suggestions, you may write them here. 